\title{
Re-ENTRY: A Holistic APPROACH TO COMBAT "THE NeW CiVIL DEATH"
}

\author{
DAVID A. HAMPTON
}

\section{INTRODUCTION}

Thank you for the honor and opportunity to participate and submit for this important symposium on Re-entry: A Holistic Approach to Combat "The New Civil Death." The topic is very thought provoking, and addresses a central question for reentry-Is it working? In my role as Deputy Mayor of Neighborhood Engagement, reentry was one of my areas of focus. I vividly recall attending the Marion County Conference on Re-entry in 2016, hosted by the Marion County Re-entry Coalition. The primary objectives of the conference were to increase the capacity of individuals and agencies that deliver services to people returning from incarceration and to promote the delivery of evidencedbased interventions. I made a few remarks on behalf of Mayor Joe Hogsett, but I was especially enlightened by the panel of formerly incarcerated individuals who eloquently spoke about their experiences re-entering society after their release from prison. Thomas Ridley's comments were most impactful as he recounted his experience upon being released from prison with nowhere to go, and a mere fifty dollars. I thought to myself, it would be very tempting and difficult not to reengage in the lifestyle that gave way to incarceration because it was lucrative. It is as if the "system" sets up its citizens for failure, knowing that the likelihood of returning to prison is greater for those experiencing poverty, or in the case of Mr. Ridley: nowhere to go, and a mere fifty dollars. Such examples beg the question, "What is the vision or goal of reentry, and is it working?" I will share more details about how the City of Indianapolis is addressing reentry, as well as the various departments tasked with a specific focus on reentry in Section II.

Recidivism is defined by the Indiana Department of Correction ("IDOC") as a "return to incarceration within three (3) years of [the offender's] release date from a state correctional institution." The 2018 Recidivism Report by IDOC compares each county's recidivism rate with the overall state average. ${ }^{2}$ The report found that $43.9 \%$ of those who came back to Marion County in 2015 returned to prison within three years of release date. ${ }^{3}$

We know that poverty is likely the strongest predictor of recidivism. ${ }^{4}$ It is a

* Deputy Mayor of Neighborhood Engagement (2016-2021), City of Indianapolis Office of the Mayor - Joseph H. Hogsett. D.Min. 2006, Christian Theological Seminary - Indianapolis, Indiana.

1. IND. DEP'T OF CORR., 2018 RECIDIVISM REPORT 2 (2018), https://www.in.gov/idoc/files/ 2018_Adult_Recidivism_CountyofCommit.pdf [https://perma.cc/U74N-F4D2].

2. Id. at 3-5.

3. Id. at 4 .

4. William Rhodes et al., Recidivism of Offenders on Federal Community SUPERVISION 18 (2012), https:/www.ojp.gov/pdffiles1/bjs/grants/241018.pdf [https://perma.cc/ 
virtual impossibility for individuals to thrive upon reentry when they cannot find employment, have no access to resources, and return to the same environment that possibly led to incarceration. ${ }^{5}$ I believe there exists a confluence of circumstances that contribute to the problem of recidivism. Poverty is the primary disease, while the symptoms or drivers that contribute to poverty are food insecurity ${ }^{6}$ mental illness, ${ }^{7}$ unemployment, ${ }^{8}$ under-employment, ${ }^{9}$ homelessness, ${ }^{10}$ and, I would add, incarceration. If poverty is the strongest predictor of recidivism, and incarceration is a driver of poverty, we can logically conclude that there exists a vicious cycle of INCARCERATION $\rightarrow$ POVERTY $\rightarrow$ RECIDIVISM, with poverty as the nexus. "Keep them impoverished, keep them imprisoned" is the implied message when there is no true dismantling of this cycle - thus, "The New Civil Death." Is reentry working? That depends upon whether we are prepared to address the crux of the matter: systematic racism and injustice. Systematic racism is dependent upon poverty to survive. Mass incarceration is dependent upon poverty to thrive. "The New Civil Death" exists if the "system" continues to penalize and marginalize those who are impoverished. It exists when the system sets citizens up for failure by not helping them to reenter their communities upon release from jail or prison. Michelle Alexander captures "The New Civil Death" in scholarly fashion in her book, The New Jim Crow: Mass Incarceration in the Age of Colorblindness, which I will further expound upon later. ${ }^{11}$

To break the vicious cycle that leads to "The New Civil Death," a more holistic approach must be realized for reentry. I will share, in-depth, Mayor Hogsett's response to addressing criminal justice reform. In 2016, the administration initiated an aggressive criminal justice reform strategy that would culminate in the construction of a new criminal justice campus. ${ }^{12}$ The overall idea of the City's initiative is to transcend merely constructing a new jail facility by including an Assessment and Intervention Center ("AIC"). ${ }^{13}$ The AIC serves as

PN5X-ZRCB].

5. Id. at 1 .

6. Id. at 1,22 .

7. Kristen M. Zgoba et al., Criminal Recidivism in Inmates with Mental Illness and Substance Use Disorders, 48 J. Am. ACAD. Psychiatry \& L., no. 2, 2020, at 1, 1.

8. Nayely Esparza Flores, Paper, Contributing Factors to Mass Incarceration and Recidivism, 6 Themis: Res. J. Just. STUd. \& Forensic SCI. 56, 59, 62 (2018).

9. Id.

10. Nino Rodriguez \& Brenner Brown, Preventing Homelessness Among People Leaving Prison, Vera InSt. Just. 1, 3 (2003).

11. See Michelle Alexander, The New Jim Crow: Mass Incarceration in the Age of COLORBLINDNESS (2012).

12. Amelia Pak-Harvey, Treatment Center Opening Next Week Begins Era of MuchAnticipated Community Justice Campus, Indianapolis STAR (Nov. 25, 2020), https://www. indystar.com/story/news/local/marion-county/2020/11/25/new-assessment-and-intervention-centerto-open-as-part-of-first-building-on-community-justice-campus/6406377002/ [https://perma.cc/VS8H-CZ2K].

13. Id. 
a resource to those experiencing mental illness, homelessness, or substance abuse issues. ${ }^{14}$ How does this address the recidivism rate? The AIC offers a diversion and alternative to incarceration, by providing temporary housing and treatment. ${ }^{15}$

Finally, I have seen some effective reentry within the Military Veteran's Model. Military veterans are supported by an organized, holistic infrastructure that addresses housing needs, employment counseling and placement, substance abuse counseling, veterans support groups, access to mental health and psychotherapy, and an entire department called Veterans Services, which I oversaw. I believe communities would see a decline in the recidivism rate if the Military Veteran's Model for reentry were adopted for criminal justice reform. Reentry programs must begin for inmates, at least six months prior to release. Pre-release programs would serve as step one of a prescribed, holistic reentry plan. Upon release, returning citizens would follow the reentry process guidelines, while enjoying the support of an infrastructure that addresses housing, employment counseling and placement, substance abuse counseling, reentry support groups, access to mental health therapy, and resources provided by a "Recidivism Reduction Program." A Recidivism Reduction Program would serve as the holistic approach to combating "The New Civil Death."

\section{THE ROOT OF THE PROBLEM: MASS INCARCERATION AND $21^{\text {sT }}$ CENTURY SLAVERY}

\section{A. The Elephant in the Room}

No true assessment of the criminal justice system would be adequate without first addressing the socio-historical and systematic injustice within. It is the elephant in the room that defines "The New Civil Death." For communities of color, any engagement with a complicit criminal justice system means a "civil death" or some semblance of a Faustian Bargain whereby one's soul is sold to that system. Whether an ankle bracelet prohibiting movement that also comes with a financial cost, or difficulty finding employment, or the inability to vote (except for probationers and parolees in fourteen states plus the District of Columbia), an encounter with the criminal justice system is crippling to those without the financial means to overcome. Michelle Alexander elucidates the damage caused by mass incarceration which she equates to the "New Jim Crow." 16 Alexander posits that "[t]hese principles are rooted in an understanding that any movement to end mass incarceration must deal with mass incarceration as a racial caste system, not as a system of crime control." ${ }^{\prime 17}$ Alexander holistically addresses the issue of mass incarceration and the racial dynamics therein. ${ }^{18}$ I would compare her use of the Jim Crow metaphor to our symposium

14. Id.

15. Id.

16. See generally ALEXANDER, supra note 11.

17. Id. at 236 .

18. See generally id. 
topic, "The New Civil Death." Whether the New Jim Crow or "The New Civil Death," mass incarceration and the recidivism rates yielded under the current system are damaging on a massive scale. ${ }^{19}$

Some scholars believe we have long since passed a tipping point where the declining marginal return on imprisonment has dipped below zero. Imprisonment, they say, now creates far more crime than it prevents, by ripping apart fragile social networks, destroying families, and creating a permanent class of unemployables. . . . Todd R. Clear's book Imprisoning Communities: How Mass Incarceration Makes Disadvantaged Communities Worse powerfully demonstrates that imprisonment has reached such extreme levels in many urban communities that a prison sentence and/or a felon label poses a much greater threat to urban families than crime itself. ${ }^{20}$

Taken within context, Clear's point does not preclude crime as a serious factor plaguing cities and communities. ${ }^{21}$ Crime and violence are no less threatening to citizens than law enforcement. ${ }^{22}$ However, if we are going to address "The New Civil Death," we must analyze the extent to which the criminal "injustice" system creates more crime in urban communities due to its devastating effects upon families as well as the devastating economic impact that creates more poverty in those communities. In other words, incarceration poses more of a threat to cities and communities than the violent crimes for which individuals are incarcerated. ${ }^{23}$

Clear assesses the impact of mass incarceration concentrated in poor places. ${ }^{24}$ He discusses how the prison population has grown because of policy choices with implications that reflect a concentration of young black men from impoverished areas in the United States population. ${ }^{25}$ Statistically,

[b]lack men are seven times more likely to go to prison than are white men; black women are eight times more likely to go than are white women.

. . 12 percent of black men between ages 20 and 40 are behind bars. White males are equally as likely to be in prison or jail as they are to be in labor unions ... ; black males are at least ten times more likely to be behind bars than in labor unions . . . . ${ }^{26}$

Clear posits that "there are three prison pressure points - the in/out ratio, length

19. Id. at 236-37.

20. Id. (citation omitted).

21. Id. at 237.

22. See id.

23. $I d$.

24. Seegenerally Todd R. Clear, Imprisoning Communities: How Mass InCARCERATION Makes Disadvantaged Neighborhoods Worse (2007).

25. Id. at 49 .

26. Id. at 63 (citation omitted). 
of stay, and the return (recidivism) rate." ${ }^{.27}$ He continues, "[T] he number of policy options available to grow prison populations without regard to the number of people eligible for prison is large indeed." ${ }^{28}$ Therefore, unless changes are made at the policy level that address an out-of-control prison population issue, the United States will continue to grapple with consequences of its own putative design.

\section{B. Urban Institute Justice Policy Center Report}

In October 2000, "the Urban Institute hosted the first 'Reentry Roundtable' meeting." ${ }^{29}$ Various scholars submitted their research for a discussion on various aspects of reentry, including the reentry process, challenges for prisoner reentry, and the implications for families and communities. ${ }^{30}$ I want to specifically focus on some of the statistics regarding race, and some conclusions drawn from the study. I realize that the data is somewhat dated; however, it helps to illuminate the point that little progress has been made to combat "The New Civil Death," even over the last twenty years.

In 1999, 476 persons per 100,000 residents were sentenced to at least a year's confinement-equivalent to 1 in every 110 men and 1 in every 1,695 women. These rates vary dramatically by race. In 1999, 1 in every 29 African-American males was sentenced to at least a year's confinement, compared with 1 in every 75 Hispanic males, and 1 in every 240 white males. One in every 472 African-American females was sentenced to at least a year's confinement, compared with 1 in every 1,149 Hispanic females, and 1 in every 3,704 white females.

...

Over the same period, the overarching jurisprudential and penal philosophy that once guided the reentry process, namely the philosophy of rehabilitation and earned reintegration within a framework of indeterminate sentencing, lost its intellectual and policy dominance. ${ }^{31}$

Again, the case is made that the primary source of concern resides at the policy level. If one were to analyze a few key criminal justice concepts regarding the prison system - retribution, rehabilitation, and reentry - the concept of retribution dominates the goal of incarceration; however, incarceration fails at rehabilitation and reentry. I maintain that this will perpetuate in the absence of a holistic approach to reentry that begins in the pre-release stage and follows returning

27. Id. at 67 (emphasis omitted).

28. Id.

29. Jeremy Travis et al., From Prison to Home: The Dimensions and Consequences OF PRISONER REENTRY 2 (2001), https://www.urban.org/sites/default/files/publication/61571/ 410098-From-Prison-to-Home-The-Dimensions-and-Consequences-of-Prisoner-Reentry.PDF [https://perma.cc/5HE9-W9CG].

30. Id.

31. Id. at 4-5 (citation omitted). 
citizens upon release.

Professor Geneva Brown further reinforces the effects of policy level decisions that negatively impact reentry:

Certain facets of reentry have changed since the implementation of the War on Drugs. The changes in sentencing philosophy directly influenced thousands of offenders facing reentry. One such change was the shift away from indeterminate sentencing, which had received heavy criticism from critics on the left and right. The left found that too much judicial discretion distorted justice. Critics from the right believed that indeterminate sentences were too low and wanted proportional punishment. By 1998, 17 states created sentencing commissions that designed sentencing grids that significantly restrained judicial discretion. Mandatory minimum sentences were enacted in all 50 states. Twentyfour states enacted three-strikes laws. Forty states enacted truth in sentencing laws, requiring offenders serve a minimum of $50 \%$ of their sentence. Some states required violent offenders to serve $85 \%$ of their sentence. $^{32}$

The dimensions of prisoner reentry described here argue for a reexamination of the nexus among the jurisprudence of sentencing, the mission of corrections agencies, the availability and quality of services for prisoners and their families, and the social goal of prisoner reintegration. At the same time, a focus on reentry reveals new ways to approach these questions, some of them quite simple, some more complex. For example, a focus on the moment of release, with its attendant risks and opportunities, suggests that correctional agencies and community groups could create new links to smooth the transition from prison to liberty. ${ }^{33}$ Something as simple as ensuring that the prisoner has proper identification, a roof over his or her head, and a community agency to report to the next day may avert some failures of the immediate transitional phase. ${ }^{34}$

Furthermore, the study revealed major questions regarding prisoner reentry and the ultimate objectives of the reentry process. I asked the question in my introduction, "Is reentry working?" Here we are in 2021, still grappling with the same issues as in 2001 . Without a holistic reentry plan and process for returning citizens, the system merely sets them up for failure.

\section{Safer Return Demonstration}

In 2015, the Urban Institute evaluated the institution of the "Safer Return

32. Geneva Brown, The Intersectionality of Race, Gender, and Reentry: Challenges for African-American Women, AM. CONST. SOC'Y FOR L. \& POL'Y 6 (2010), https://www.acslaw.org/ wp-content/uploads/2018/04/Brown-issue-brief-Intersectionality.pdf [https://perma.cc/YDY6$\mathrm{K} 5 \mathrm{FY}]$ (citations omitted).

33. Id.

34. TRAVIS ET AL., supra note 29, at 46. 
Demonstration," a research-based community reentry initiative. ${ }^{35}$ "The Safer Return demonstration began with the basic premise that[, on three fundamental levels, necessary] policies and procedures to adequately support prisoner reentry were lacking." ${ }^{36}$ First, the journey from prison life to community reintegration was not seamless and was often complicated. ${ }^{37}$ On the individual and family level, returning prisoners were ill-prepared to navigate routines in their home communities, and their families were similarly unprepared to proactively support them in achieving positive outcomes. ${ }^{38}$ Second, on the systems level, public state, county, and city agencies and private service organizations were ill-prepared to provide coordinated supports for individuals returning from prison. ${ }^{39}$ Without such supports, public safety, community stability, and individual outcomes remained at risk. ${ }^{40}$ Third, on the community level, entire neighborhoods were unable to meet the complex needs of returning individuals; communities were weakened by the individuals' past criminal activities and their ensuing absence during incarceration, and then burdened by their return. ${ }^{41}$ Again, the issue of policy as a driver of failed or deficient reentry is identified. As I build my case around the need for a Recidivism Reduction Program, it is apparent that the consensus calls for a holistic approach that includes pre-release and prisonerrelease engagement, systems level wrap-around services, and a support infrastructure designed to meet the needs of returning citizens. ${ }^{42}$

\section{Finding Solutions: Ohio Plan}

I am impressed by the mission statement and plan initiated in Ohio under former Governor Bob Taft in 2002. ${ }^{43}$ Again, I am offering somewhat dated material, but it serves to reveal one of the efforts made by a neighboring state. The Executive Summary of the Ohio plan states:

The Ohio Plan for Productive Offender Reentry and Recidivism

Reduction provides a comprehensive set of recommendations addressing the transition of offenders from reception to their parent institution to

35. Jocelyn Fontaine et al., Urban Inst., Safer Return Demonstration: Impact Findings From a ReSEARCh-BASEd COMmunity REENTRy Initiative (2015), https://www. urban.org/sites/default/files/publication/56296/2000276-Safer-Return-Demonstration-ImpactFindings-from-the-Research-Based-Community-Reentry-Initiative.pdf [https://perma.cc/LH6CT7FD].

36. Id. at vii.

37. Id. at 130-32.

38. Id.

39. Id. at 131 .

40. Id.

41. Id. at 130-32.

42. Id.

43. The Ohio Plan for Productive Offender Reentry and Recidivism Reduction, Оніо DeP'T REHABILITATION \& CORRECTION (July 2002), http://dsosborn.pbworks.com/f/ohio+reentry+ plan+2005.pdf [https://perma.cc/JQ6K-Q39K]. 
supervision in the community. The recommendations were formulated by six Reentry Action Teams working under the auspices of a departmental Reentry Steering Committee. The teams focused on six major areas affecting offender reentry: Offender Planning and Tracking, Offender Programming, Discharge Planning and Employment, Family Involvement, Offender Supervision, and Community Justice Partnerships. What follows presents forty-four recommendations organized by the area of reentry into which they fall.

\section{RECEPTION, OFFENDER ASSESSMENTS, AND REENTRY PLANNING \\ Recommendation \#1: The reception assessment process shall be} augmented to include a formal risk assessment and needs assessment.

Recommendation \#2: Reentry Accountability Planning shall occur for offenders based on their risk level and time to be served while at reception, the parent institution, and, if applicable, during the period of parole or post-release control supervision.

Recommendation \#3: Reception, Institutional, and Community Reentry Management Teams shall be responsible for developing and monitoring Reentry Accountability Plans for designated offenders throughout the reentry transition process.

Recommendation \#4: A Department Offender Tracking System(DOTS) screen shall be developed that will contain the Reentry Accountability Plan accessible to appropriate staff at any stage in the reentry transition process.

Recommendation \#5: A reception process standardization team with staff from each reception center and central office shall be formed to standardize the reception protocol, procedures, staffing and timelines for accomplishing their work.

Recommendation \#6: The reception centers shall put a system in place to ensure that presentence investigation reports, violation reports, and offender background investigations, if applicable, are part of the master file.

Recommendation \#7: The reception centers shall provide program recommendations to the Bureau of Classification to be considered in the offender's assignment to the parent institution, along with the offender's security level, length of sentence, bed space, and other such considerations.

Recommendation \#8: The existing link on the Department's Internet website shall be revised to include the Adult Parole Authority (APA) regional Administrative Assistants and Regional Service Coordinators. The Administrative Assistant shall serve as the designated liaison for outside agencies and the courts. The reception centers shall also designate a liaison to work either with the APA Administrative Assistant or be a direct contact for outside agencies and the courts to be included on the Department's Internet website.

Recommendation \#9: A comprehensive series of steps shall be taken to 
ensure that presentence investigation reports arrive with the offender at reception. To streamline the reception process, similar steps shall be taken to obtain violation behavior for returnees.

\section{OFFENDER PROGRAMMING: TARGETING CRIMINOGENIC} NEEDS

Recommendation \#10: New programs that are developed shall incorporate the principles that drive effective correctional programming, provide staff training prior to their adoption, and be guided by a training manual that directs all work relevant to the program. They shall be reviewed and approved subject to their compliance with a standardized protocol to be established in Departmental policy.

Recommendation \#11: Existing programs shall be reviewed and maintained or eliminated based on the extent to which they address the dynamic domains used to assess offender needs as part of reentry planning. Departmental resources will be allocated over time to support existing programs that effectively address these areas, as well as to create treatment interventions in offender needs areas where additional programming is necessary.

Recommendation \#12: An Ohio Offender Performance Merit System shall be developed and adopted that recognizes pro-social behaviors by offenders enrolled in reentry programming.

Recommendation \#13: The Classification Policy (\#111-07) shall be revised to allow appropriate offenders in medium and minimum levels the opportunity to receive points for reentry programming that is completed in order to earn a reduction in their security level.

Recommendation \#14: An Interdisciplinary Special Needs Offenders Management Work Group shall be formed to oversee the adoption of a series of "best practices" associated with the reentry transition for offenders, including sex offenders, older offenders, mentally ill offenders, and mentally retarded or developmentally disabled offenders.

\section{FAMILY INVOLVEMENT IN REENTRY}

Recommendation \#15: A Family Orientation Program shall be implemented at each reception center with information disseminated on community resources.

Recommendation \#16: Community-based support groups shall be developed for family members through the Offender Services Network and the Department's faith-based initiative.

Recommendation \#17: A Family Council shall be formed to address offender/family issues across the reentry continuum.

Recommendation \#18: The policy on Inmate Visitation (\#312-02) shall be revised to remove barriers prohibiting family members from visiting and provide for the reactivation of the visitation list for parole violators. Post specific training shall be provided for staff working in the visiting area to familiarize correctional officers with handling family members and the public. 
Recommendation \#19: The policy on Unit and Treatment Programming (\#315-05) shall be revised to support the involvement of family members in institutional programs.

Recommendation \#20: A new policy on family/child-centered programming for incarcerated mothers and fathers shall be developed that includes a provision for additional visits for participation in selected programming.

Recommendation \#21: The curriculum for the current "Responsible Family Life Skills Program" shall be revised to include a lesson plan on child support and paternity.

Recommendation \#22: A pilot program shall be established creating a treatment community in a designated institution focusing on family life education and reunification.

Recommendation \#23: A family component shall be developed in cooperation with existing Therapeutic Community and institutional security staffs allowing immediate family members to participate in the rehabilitative process.

Recommendation \#24: Adult Parole Authority (APA) policies \#501-19, \#501-30, and \#501-35 shall be revised to include family members in the supervising officer's planned visits with the offender and in the initial office visit, and to disseminate information explaining the responsibilities of the APA, as well as encouraging family involvement.

Recommendation \#25: New collaborative arrangements shall be forged with the Department of Education and the Department of Jobs and Family Services addressing school/parent issues associated with the children of the incarcerated.

Recommendation \#26: New collaborative arrangements shall be forged between child welfare and DRC to develop cross-system ties and training between the two agencies.

EMPLOYMENT READINESS AND DISCHARGE PLANNING

Recommendation \#27: A new policy called "Transitioning the Offender" shall be adopted to ensure that thorough discharge planning takes place to prepare offenders for release to the community. The policy shall include a new form entitled the "Discharge Planning \& Employment Readiness Checklist," to monitor the reentry transition process.

Recommendation \#28: One comprehensive policy shall drive all programs dealing with offender release preparation entitled the "Release Preparation Program" (\#313-01). This new policy combines and integrates two separate DRC policies (\#313-03 and \#313-04) that formerly governed all pre-release programs.

Recommendation \#29: A Reentry Resource Center will be located in the library of each institution and each APA regional office. The current DRC policy on libraries (\#106-01) shall be revised to include the establishment of such centers in prison libraries.

Recommendation \#30: The Department will implement a Career 
Exploration Program at all institutions to assist offenders in making decisions regarding education, training, and employment. Career resource material will be available within the Reentry Resource Centers to support career exploration.

Recommendation \#31: The inmate's work ethic shall be enhanced by the adoption of policy revisions involving (\#108-02) "Classification and Reclassification Status Review," proposed revisions to the current Administrative Rule (\#5120-3-08); the creation of a new policy called the "Offender Work Ethic," and revisions to the Job Coordinators' position description.

Recommendation \#32: Comprehensive strategies and carefully targeted policy changes shall be adopted to improve the marketing of job ready ex-offenders, inclusive of the following.

- Revisions to the Career-Technical Education policy (\#105-12) will be made to improve the dissemination of the Career Passport, a marketing tool for career -technical program completers;

- A new strategy for marketing job-ready offenders to be incorporated within the Release Preparation policy (\#313-01) will include the use of quarterly employer interviews for career technical, apprenticeship or advanced job training students nearing release;

- The use of the Ohio Job Net System will allow Job Coordinators to pre-register career technical students and apprentices nearing release. This will improve the marketing of selected offenders by registering for work, using the intranet link to the Ohio Department of Jobs and Family Services;

- A new policy related to educational, vocational and employment follow-up of offenders after release from prison will be adopted. This policy will address the Code of Employee Conduct, specifically professional contact with offenders after release.

- Revisions shall be adopted in two APA policies (\#501-49 and \#50131) that will support the collection of information on the employment status of parolees during the classification reassessment process and at termination from supervision.

\section{REENTRY-CENTERED OFFENDER SUPERVISION}

Recommendation \#33: The Adult Parole Authority shall be guided by a philosophy of supervision that calls for a balanced approach in working with offenders. This approach emphasizes community safety, offender accountability, and community-based programming that facilitates effective reentry.

Recommendation \#34: The Adult Parole Authority shall adopt community and neighborhood-based supervision strategies that include reporting centers in local neighborhoods and the use of geo-mapping to allocate staff and resources to where offenders reside.

Recommendation \#35: The Citizens' Circle Model involving community-collaboration and partnerships with the Adult Parole Authority currently in operation in several sites shall be implemented in 
all parole regions.

Recommendation \#36: Prior to release, parole officers will provide reentry orientation sessions at the institutions to convey the expectations of supervision, offenders' responsibilities, and the role and responsibilities of parole officers and Offender Services Network staff in supporting successful reentry.

Recommendation \#37: Revisions shall be made in the Adult Parole Authority's Violations Sanctions Policy supportive of reentry goals and that structure and provide statewide consistency in the use of progressive sanctions.

\section{COMMUNITY JUSTICE PARTNERSHIPS}

Recommendation \#38: A Faith-Based Advisory Council has been newly established to ensure that members of the faith community from across the state are actively engaged in the continuum of offender reentry. The Council shall develop a strategic plan and establish regional councils to assist in reentry initiatives at the local community level.

Recommendation \#39: The Department of Rehabilitation and Correction shall sponsor an annual conference involving faith-based communities and other agencies from across Ohio to educate and provide information, and to identify issues and barriers relevant to offender reentry.

Recommendation \#40: A comprehensive review of two Departmental policies (Volunteers \#312-01 and Visitation \#312-02) relevant to establishing relationships with offenders supportive of reentry shall be conducted and revisions shall be made to support faith-based, and other community partnerships throughout the reentry transition.

Recommendation \#41: The Religious Services Department shall oversee the development of a uniform assessment instrument called an "Individual Faith Treatment Plan" that will be administered to offenders at reception.

Recommendation \#42: The Office of Victim Services shall contact victims involved in identified higher risk cases to address victim safety planning needs.

Recommendation \#43: The Office of Victim Services shall coordinate the development of a research instrument and the completion of research on victim awareness programming currently offered by the Department of Rehabilitation and Correction.

Recommendation \#44: The Office of Victim Services shall develop a standardized curriculum for domestic violence programs within the institutions. $^{44}$

The current three-year recidivism rate in Ohio is $31.45 \% .{ }^{45}$ Comparatively,

44. Id. at i-v.

45. Recidivism Rates by State 2021, World Population Rev., https://worldpopulation 
here in Indiana, "[o]f the people released in 2018, 33.78 percent returned to prison for either a new conviction or a parole violation." ${ }^{36}$ Further, "[u]nder those same parameters, the recidivism rates for 2013-2017 are 35.85 percent, 37.6 percent, 38.17 percent, 36.99 percent, and 33.87 percent." ${ }^{\prime 47}$ Indiana lags slightly behind Ohio, but the overall recidivism rates have declined and are the lowest in six years. ${ }^{48}$ Statistics show that when a holistic approach is applied to reentry, a reduction in recidivism follows. ${ }^{49}$ As we can see, a robust reentry plan reduces the recidivism rate for states that are intentional.

My good friend Dr. William Oliver, retired professor of criminology at Indiana University, Bloomington, gave a 2019 lecture on reentry. Based upon some of the notes I have, he listed the following barriers to reentry that must be addressed to reduce recidivism rates:

- "Most prison systems do little to facilitate a smooth transition from prison to community." 50

- "One third of all state departments of corrections report that they do not provide any funds upon release." ${ }^{11}$

- $80 \%$ of returning offenders have a history of substance abuse..$^{52}$

- $40 \%$ received drug treatment. ${ }^{53}$

- $60 \%$ did not receive drug treatment. ${ }^{54}$

- Inadequate plan to access a continuity of care as mentally ill prisoners transition from prison to the community. ${ }^{55}$

- Inadequate collaboration and partnership with community-based mental health service providers. ${ }^{56}$

- Difficulty obtaining government-issued identification (birth certificate, social security card, driver's license).$^{57}$

review.com/state-rankings/recidivism-rates-by-state (last visited Feb. 14, 2021) [https://perma.cc/ M6LU-F68E].

46. Courtney Crown, Indiana's Recidivism Rates Lowest in 6 Years; Women in Prison Stay on Right Track with Special Programs, Fox 59 (Aug. 2, 2019), https://fox59.com/news/ indianas-recidivism-rates-lowest-in-6-years-women-in-prison-stay-on-right-track-with-specialprograms/?fbclid=IwAR2JYJpyASdyOlhN5KGaItBR57C4TQB8Spadd_jEIFTNfBUF3qtehrU Vwuo [https://perma.cc/XJQ8-Y8Z2].

47. Id.

48. Id.

49. See Travis ET AL., supra note 29, at 17.

50. William Oliver, Associate Professor Emeritus, Indiana University, Lecture (2019) (notes on file with author) (quoting Christy A. Visher \& Jeremy Travis, Transitions from Prison to Community: Understanding Individual Pathways, 29 ANN. REV. Soc. 89, 96 (2003)).

51. Id. (quoting Visher \& Travis, supra note 50, at 96).

52. Id.

53. $I d$.

54. Id.

55. $I d$.

56. Id.

57. Id. 
- Result: Hinders access to public aid and the search for employment. ${ }^{58}$

- Incarceration Stigma:

- An employer survey found that two-thirds of employers would not knowingly hire an ex-offender. ${ }^{59}$

- Increased use of criminal history records as part of hiring decisions. ${ }^{60}$ Reentry programs that address these persistent issues will have done their part to combat "The New Civil Death."

\section{A CITY’S SOLUTION: CITY OF INDIANAPOLIS CRIMINAL JUSTICE REFORM INITIATIVES}

\section{A. Criminal Justice Reform}

In 2016, I was assigned to the Indianapolis Criminal Justice Reform Task Force. My role was to gather and engage community stakeholders through a series of public information forums. Mayor Hogsett set forth Executive Order No. 4, 2016, which commissioned the Task Force, as well as plans to construct a new criminal justice center ("CJC"). ${ }^{61}$ The CJC is part of a "holistic approach to addressing crime" in Marion County, with a focus "on connecting residents with employment, mental health or other services" as an alternative to jail or incarceration. ${ }^{62}$ Overall, the plan addresses "public health problem[s] fueled in part by racial inequity." "63 The CJC will include an AIC (Assessment and Intervention Center), designed "to provide temporary housing to residents experiencing homelessness[,] . . mental health[,] or substance abuse issues." ${ }^{\prime 64}$ The AIC can hold sixty beds but will be scaled down to thirty due to the COVID19 pandemic. $^{65}$ The remainder of the Community Justice Campus is set to open in $2022 .^{66}$

The Task Force prepared a summary report, with which I assisted, of its findings and recommendations:

\section{Goal}

On May 11, 2016, in his inaugural State of the City Address, Mayor Joe Hogsett set Indianapolis on a path toward holistic, data-driven criminal justice reform by signing Executive Order No. 4, 2016, launching the Indianapolis Criminal Justice Reform Task Force (the "Task Force").

"The Mayor hereby creates and orders his staff to support the Criminal

58. Id.

59. Id.

60. Id.

61. Consolidated City of Indianapolis \& Marion Cty. Exec. Order No. 4, 2016 (May 11, 2016).

62. Pak-Harvey, supra note 12.

63. Id.

64. Id.

65. Id.

66. Id. 
Justice Reform Task Force whose mission shall be to assess, research, examine, and ultimately report recommendations for the systemic reform and optimization of the current county criminal justice system."

In a report released on December 12, 2016, the Task Force recommends a series of reforms to the criminal justice system that will improve health and safety in Indianapolis, prevent crime, and redirect offenders back to a successful life in the community at the earliest possible point in time.

\section{Organization and Community Engagement}

From the outset, the Task Force was dedicated to a culture of inclusion that would build consensus and credibility among community and neighborhood groups. To assist in that effort, ten community engagement events were held across the city over the last few months to provide all citizens an opportunity to have their voices heard. In addition, invaluable input was gathered from the following stakeholder organizations:

ACLU of Indiana

Central Indiana Community Foundation

EmployIndy

Greater Indianapolis NAACP

Greater Indianapolis Progress

Committee

Health Foundation

Indiana Department of Correction

Indiana University Health
Indy Chamber

Indy Chamber Workforce Policy

Council

IndyCAN

Marion County Reentry Coalition

Mental Health America of Indiana

Recycle Force

The Richard M. Fairbanks

Foundation

Indianapolis Bar Association 

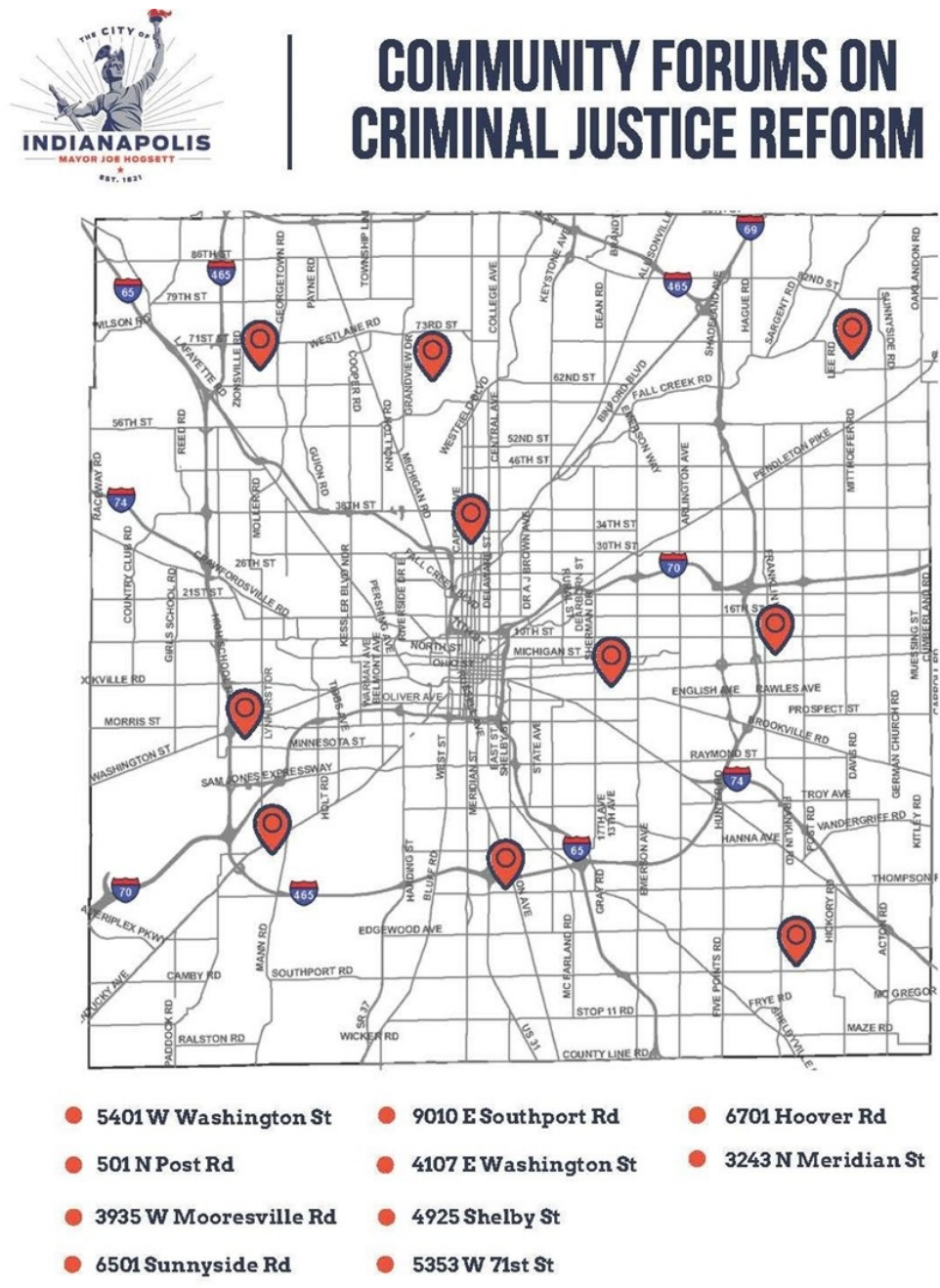

Additionally, the Task Force includes bipartisan representation from all twenty-five members of the City/County Council and the Chief Financial Officer of the Council.

Finally, and most importantly, the Task Force includes internal government stakeholders who work every day in the Marion County criminal justice system. These individuals participated in dozens of work sessions over the past six months. The following offices and agencies are represented on the Task Force: 


Health \& Hospital Corporation of
Marion County
Indianapolis Metropolitan Police
Department
Indianapolis Office of Public Health \&
Safety
Indy EMS
Marion County Circuit Court
Marion County Clerk's Office

\author{
Marion County Community \\ Corrections \\ Marion County Coroner's Office \\ Marion County Forensic Service \\ Agency \\ Marion County Prosecutor's \\ Office \\ Marion County Public Defender \\ Agency \\ Marion County Sheriff's \\ Department \\ Marion County Superior Court
}

\section{Findings}

\section{A. Condition of Facilities}

The need for new facilities to improve the safety, security and basic operations of the Marion County justice system is well established and has been studied extensively over the past 30 years. Criminal Justice stakeholders currently operate in a variety of buildings in multiple locations around the county.

The Marion County Superior and Circuit Courts have operations at four separate sites, including the City-County Building, Juvenile Detention Center, Traffic Court, and the Arrestee Processing Center (APC). The Sheriff detains and houses incarcerated offenders at four separate facilities, including the Arrestee Processing Center, Jail I, Jail [II], and Hope Hall in the City-County Building. The aggregate capacity of detention space is 2,300 inmates, after making allowances for the need to certain segments (e.g., gender, juvenile offenders, gang members) of the population for security reasons.

Marion County Community Corrections (MCCC) operates four (4) residential facilities, comprised of 597 beds, for offenders sentenced to work release, transition, mental illness treatment, re-entry programming and related programming. MCCC also provides substance abuse treatment, drug and alcohol testing services, electronic monitoring and case management services.

The Marion County Forensic Services Lab, IMPD Property Room and Marion County Coroner's Office have intertwining operations that are carried out in multiple spaces, including Jail I, the City-County Building and the Coroner's Office. All three are housed in spaces that are insufficient for space needs, inefficient for technical needs, or hamper operations.

The Marion County Prosecutor's Office and the Marion County Public Defender Agency, respectively, are parties to long-term leases in walking distance from the City-County Building that meet the operating needs of both agencies. The location of the offices in separate buildings secures confidentiality, security and segregation of witnesses, offenders and 
victims

Finally, the Reuben Engagement Center, set to open in early 2017, will offer shelter and connection to community services, but will not be equipped with space for medical and behavioral health services envisioned under a reformed criminal justice system.

With the exception of the Prosecutor and Public Defender operations, most current facilities were not originally designed for their current use and significantly hamper the ability of Criminal Justice partners to realize economies of scale, use resources effectively - staff, technology, and space - and engage in an integrated flow of work.

A Criminal Justice Campus that accommodates the collective needs of a reformed and modern county justice system would incorporate the use of technology such as e-filing[;] courtroom video conferencing; appropriate spaces for counsel/client conferences; the provision of medical, mental health and social services for both diversion and inhouse cases; house flexible courtroom spaces; allocate appropriate number of beds for inmates, but also for mental health and addiction patients diverted from incarceration; and support the efficient flow of a system that is based upon the reforms recommended in this report.

\section{B. Offenders}

Inmates in all three Marion County Jails are classified and housed often in segregated units based [on] a variety of factors including the severity of their crimes, gang affiliations, age, gender, and mental and physical illness. On the average, $30-40 \%$ of the inmates are classified as mentally ill. $85 \%$ of the inmates have substance abuse problems. More than 37,000 patients are treated for medical services at the Jail Special Care Unit each year.

$84 \%$ of detainees in Marion County's jails are under custody in predisposition, or prior to trial or hearing.

Under the care of our current contracted health care provider, more than 700 prescriptions are distributed to mentally ill inmates every day at a cost of $\$ 650,000$ per year. The contractual cost of the care for mentally ill inmates is $\$ 5$ million per year and the cost of separate security for mentally ill inmates i[s] \$2.1 million annually. The Sheriff has estimated that the total cost for the care and custody of mentally ill inmates is $\$ 7.7$ million. The segregation of mentally ill inmates in separate jail units or isolated in "suicide watch" units further drives personnel costs as a result of the need for increased direct supervision.

Drugs and Addiction

Over the course of 45 years and after the expense of more than $\$ 1$ trillion, the War on Drugs (focused on Crack Cocaine in the 1980s and Opioids more recently) has resulted in a more than 10-fold increase in the number of incarcerated drug offenders in state and federal prisons. These drug epidemics also impact the families of drug addicts, evidenced as on example, by increased cases of the number of Children in Need of Services (CHINS) - more than a 65\% increase in Marion County over five years. 
Mental Illness

Insufficient points of access, inability to maintain engagement, and inadequate service capacity for poor and homeless with mental illness has made Marion County jails a default provider for mental health and addiction treatment.

Mass incarceration

Studies and current data make clear the disparate impact of mass incarceration policies on people. For example: those who are poor and in custody because they cannot afford to pay fees or bail; ethnic and racial misrepresentation; and the question of how to reduce the numbers of arrestees. African Americans comprise $52 \%$ of the jail population in Marion County as compared to $28 \%$ of the [c]ounty population. Whites are $46 \%$ of the jail population and $65 \%$ of the county population.

Repeat Offenders

A report by $\mathrm{BKD}$ on the Marion County criminal justice system concluded that "a significant number of individuals with multiple arrests can be identified, and these arrestees take up a disproportionate number of criminal justice resources." These repeat offenders can be described as "super utilizers" or individuals who interact with a particular public safety or public health agency repeatedly at great expense to taxpayers.

\section{Process Delays}

Marion County criminal justice organizations are many, and they interact deeply with one another in myriad ways. Issuing arrest warrants, transporting, holding, and identifying offenders, assessing risks, deciding and communicating sentences. The number of organizations and interactions makes criminal justice a highly interwoven system of many parts, driven by each stakeholder's legal duty and influenced by leadership, budgets, structure, process design, and flow of information. Approximately 50 meetings with the criminal justice stakeholders, including IMPD, the Marion County Sheriff, the Marion County Prosecutor, the Public Defender, the Superior Courts, the Marion County Clerk, Marion County Probation, Marion County Community Corrections, Marion County Forensic Services Agency, and the Marion County Coroner were held to map and analyze current processes. Multiple points of rework and delay were identified for improvement.

The chart below shows the number of offenders who spend 5 or fewer days in jail, only to be released. Unintended delays result in harm to offenders - such as decompensating mental health and loss of employment. Diverting a greater number of offenders from incarceration would reduce the costs to the County. At the taxpayer cost of $\$ 83.17$ per day, the cost to jail these 23,530 inmates is estimated at $\$ 2,972,579$. Disposition of even half of the cases with a stay of one or less days generates an estimated $\$ 700,000$ savings. 


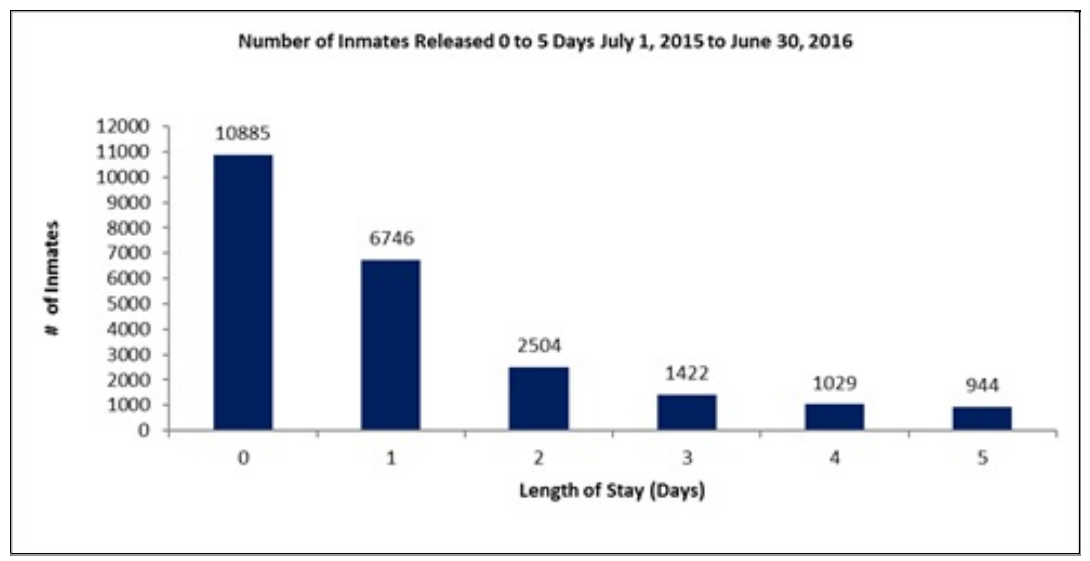

\section{Recommendations}

\section{A. Address Root Causes of Crime}

In Mayor Hogsett's Inaugural Address, he outlined three challenges facing the city: a violent crime epidemic, the exponential rise in poverty, and a $\$ 50$ million a year structural deficit. The intersection of mental illness, substance abuse, as well as addiction and poverty exacerbate these challenges - overburdening the criminal justice system, creating cycles of recidivism, and contributing to generational poverty.

The Task Force's recommendations focus on identifying non-violent, low-level offenders suffering from serious mental illnesses and drug addiction and diverting them from the criminal justice system. This begins with providing every officer and E911 operator with crisis intervention training and a mental health assessment tool to aid in identifying underlying conditions. The report also proposes a new system for diverting individuals to treatment before an arrest is even warranted with the creation of Mobile Crisis Units made up of officers, paramedics, and crisis counselors. Lastly, the Task Force recommends the creation of an Assessment and Intervention Center for those suffering from mental illness and addiction.

\section{B. Sequential Intercept - The Indianapolis Model}

The Sequential Intercept Model (SIM) addresses mental illness and addiction in the criminal justice system. SIM provides a framework for communities to design the interface between the criminal justice, mental health, and social service systems.

SIM defines a series of points of interception, or opportunities for an intervention, to prevent individuals with mental illness from entering or penetrating deeper into the criminal justice system. Those points include: (1) law enforcement and emergency services, (2) initial detention and initial hearings, (3) jail, courts, forensic evaluations, and forensic commitments, (4) reentry from jails, state prisons, and forensic 
hospitalization, and (5) community corrections and community support services.

The task force recommends the Indianapolis Model - a pre-arrest, postarrest, pre-trial services and detention initiative:

\section{Indianapolis Model}

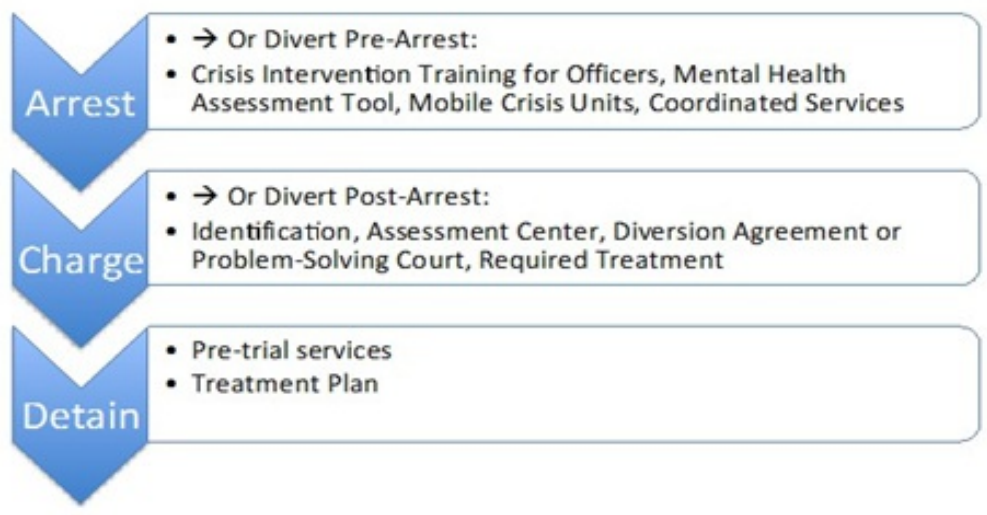

\section{Pre-Arrest Diversion}

a) CIT Training

The Task Force recommends that every E911 operator and IMPD officer be fully CIT trained by the conclusion of 2018. CIT training provides E911 operators and police officers the ability to: (1) quickly and effectively identify those suffering from mental illness and/or addiction upon dispatching, or being dispatched to, a particular incident, (2) address the immediate situation, and (3) initiate the appropriate channeling of the individual.

b) Mental Health Assessment Tool

Data-driven assessment tools enhance an officer's ability to utilize the CIT training they receive. The city, through the Office of Public Health \& Safety, will work with the New York University School of Law to develop a data-driven mental health screening tool specific to Indianapolis.

c) Mobile Crisis Units

Mobile Crisis Units consist of a police officer with enhanced CIT training paired with one or more public health professional. IMPD and HHC (via Midtown Mental Health and Indy-EMS) will establish and pilot a collaborative MCU Service Line. The MCU will be comprised of a law enforcement officer (LEO), a social worker, and EMS personnel. The unit will expand today[']s existing IMPD Behavioral Health Unit to respond to 911 mental/emotional/ 
substance-abuse calls as well as daily referrals and follow up care. At the outset, MCUs will be piloted in one targeted IMPD district to operate twenty-four hours a day, seven days a week. The results of the pilot period will be analyzed to appropriately scale and then implement a city-wide deployment of MCUs.

\section{Post-Arrest Diversion}

Often, those suffering from mental illness and/or addiction are arrested for low-level, non-violent offenses, and then repeatedly arrested for the same or a similar offense. The more often (and further) an individual enters the criminal justice system (even if only for a few hours or a few days) the worse the outcome for the individual and the community.

a. An officer or MCU may, in making an arrest of a low-level, nonviolent offender that they believe is suffering from an underlying mental illness and/or addiction, nominate the individual for enhanced assessment upon normal arrestee processing.

b. Because an enhanced assessment exists outside of typical arrestee processing, candidates for post-arrest intervention and diversion may be provided defense counsel immediately upon arrival and initial processing.

c. Once normal arrestee processing is complete, and upon advice of defense counsel, a candidate will enter the Assessment \& Intervention Center for enhanced assessment by public health professionals of Health and Hospital Corporation of Marion County. Enhanced assessment will include, but not be limited to, physical health, mental health, addiction, housing, family, and veteran status.

d. Once the arrestee processing process and enhanced assessment are complete, the prosecutor, perhaps in consultation with the candidate's defense counsel, may elect to: (1) offer the candidate a diversion agreement that would encompass a treatment plan developed by a medical professional with other legal requirements, (2) charge the individual, but refer the case to the appropriate problem-solving court, or (3) determine that the case will proceed in the normal course.

e. A treatment plan is developed.

NOTE: The Task Force recommends implementation of this program as a pilot. Similar to the pre-arrest intervention and diversion pilot, the results of the post-arrest pilot period will be analyzed to appropriately scale the operations and construction of the proposed Assessment \& Intervention Center.

\section{Pre-Trial Services}

The vast majority of individuals in the Marion County criminal justice system are pre-disposition and most are not detained pretrial. Pre-trial service agencies connect pre-disposition individuals to services targeted at their specific needs and offer a variety of other best practices that promote adherence to the terms of pretrial release and the prevention of recidivism (for example, something as simple as a call or text reminding an individual of a pending court hearing). 
The Task Force recommends that the Office of Public Health and Safety work in conjunction with the Marion Superior Court to develop a pilot pretrial services program within the Marion County Probation Department, seek grant funding for the program, implement the services program concepts, and analyze the resulting collaboration for effectiveness (primarily such services['] effect on recidivism).

\section{Bail Reform}

Communities and courts all over the country are moving away from the "cash bail" system. Proponents of bail reform argue that cash bail denies freedom to thousands of people who are presumed innocent but cannot afford their bond. On September 7, 2016, the Indiana Supreme Court issued an order adopting Criminal Rule 26 that states:

If an arrestee does not present a substantial risk of flight or danger to themselves or others, the court should release the arrestee without money bail or surety subject to such restrictions and conditions as determined by the court except when:

(1) The arrestee is charged with murder or treason.

(2) The arrestee is on pre-trial release not related to the incident that is the basis for the present arrest.

(3) The arrestee is on probation, parole, or other community supervision.

The Task Force recommends that the Office of Public Health \& Safety work in conjunction with the Marion County Superior Court to get Marion County ahead of the curve by seeking grant funding for the study, design, and implementation of a pre-trial risk assessment tool specific to Marion County's needs.

\section{Process Changes to Reduce Rework and Delay}

The Task Force recommends implementation of the following process changes to improve performance of the current system of criminal justice:

- Identification of offenders - take one photo and use electronic fingerprints

- All agencies use the FBI number

- All agencies use standard sentence codes All agencies use the bond module

- Sheriff has defined authority and flexibility of offender placement

- All confiscated drugs are tested

- Use electronic traffic tickets and automatic summons

- Central evidence storage under forensic services

\section{E. Data Driven Continuous Improvement as One Indy}

The task force is encouraged by the collaboration among highly motivated leaders of Indianapolis health and criminal justice systems. We will continue to support and grow the collaboration. We will glean all we can from our information, provide visual analysis for stakeholders, discuss best methods, test actions, and make decisions. We will continue to track our results and adjust our strategies as indicated by the data. 


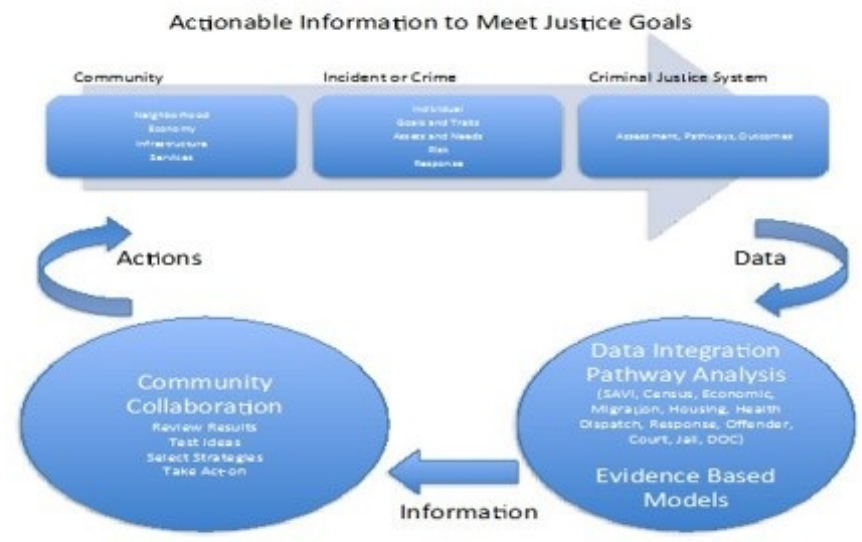

\section{F. Facilities}

The Task Force recommends constructing new facilities to suit the criminal justice design and process changes discussed in this report. The following are included in the recommended features and design:

1. Assessment and Intervention Center where arrestees are assessed for mental health and substance abuse treatment needs, receive shortterm detoxification and behavioral health treatment, have access to social services, defense counsel and prosecutor staff, receive referrals to longer-term treatment plans and engagement with the wraparound care services based on individual treatment plans.

2. A 2,600 - 3,000 bed jail to replace current detention facilities, with design elements that increase safety for jail staff and inmates by facilitating improved admission and inmate management[.]

3. Acute health care and mental health units that accommodate stateof-the-art care including suicide watch, geriatric, and chronic disease care.

4. A consolidated Civil and Criminal Courthouse that incorporates the design elements defined by a Courts Planning Group and collocated with the AIC and new Jail. The final determination of design and courts included will be made by the Marion County Judiciary.

5. Contingent relocation of the Marion County Prosecutor's Office and Marion County Public Defender Agency if the Criminal Courts are relocated to the new Justice Complex.

6. Renovate and reuse the APC, Jail II facilities and space in the 
City-County Building if vacated by the courts, for Community Corrections and collocation of the IMPD Property Room, Crime Lab and Marion County Coroner's Office.

Parameters for site selection

The CJR Task Force further recommends that the new facilities be located in a campus setting that is accessible and enhances the aesthetics and economic and community development prospects of surrounding neighborhoods. Additional considerations in site selection include:

- Public Safety, taking into account and minimizing adjacent uses such as residential areas, churches and schools.

- Ability to accommodate[] all facilities, as a combined, efficient facility is the best option for cost, efficiency and public safety.

- Cost structure

- Proximity and Access to Constituent Groups[, a] central location, and access to public transportation

\section{Finance}

The proposed reforms to our local criminal justice system will be a costly undertaking and an important investment in our city's future. The financing of the project begins by determining what the City can afford without a tax increase.

So far, the Task Force Finance Team has identified an annual \$35 million from current resources that can be reallocated to fund costs of construction, operating expenses and programming of a reformed criminal justice system.

\section{Notes:}

- Sheriff personnel savings from reduction in transportation expenses and overtime

- Core Civic contract estimated savings at \$14 million. Additional \$2.5 million in savings from Medicaid reimbursements

- Revenue from HB1006 inmates at $\$ 35$ per day estimating 150 inmates

- Additional funding for this project could result from efforts to repurpose sites that will be vacated by criminal justice agencies[]

- We recommend utilizing existing revenues that may become available as a result of actions of other taxing authorities $\cdots$

\section{Timeline}

December 12, 2016: Presentation of report to county's Criminal Justice Planning Council

January 31, 2017: Criminal Justice Reform Task Force makes justice complex location recommendation

February 28, 2017: Task Force completes cost estimate

March 31, 2017: Announce finance and construction plan

May 1, 2017: Judiciary announces courts plan 
July 1, 2017: Release of bids for justice campus project November 1, 2017: Bid responses due back to city January 1,2018: Bid selected and proposal to Council ${ }^{67}$

\section{B. OPHS - Office of Public Health \& Safety}

Mayor Hogsett established the Office of Public Health \& Safety in response to the need to address the corollaries between issues of public safety, and public health. ${ }^{68}$ The two issues are combined into one office. ${ }^{69}$ Reentry is among the various departments that reside under OPHS. ${ }^{70}$

OPHS works with community partners to help ex-offenders re-enter the Indianapolis community. While criminal history should not get in the way of self-sufficiency, many formerly incarcerated individuals struggle to get back on their feet. It often takes a network of supportive services, especially in housing and employment, to help someone successfully return to the community. ${ }^{71}$

OPHS also engages with a network to provide food, and other wrap-around services in response to the need to reduce the recidivism rate. ${ }^{72}$

"Successful re-entry reduces the number of formerly incarcerated individuals who will cycle back through the criminal justice system by committing repeat offenses." ${ }^{\prime 3}$ One example of a successful program was the Re-entry Job and Resource Fair, which provided legal assistance (expungement advice, license reinstatement, child support), employment assistance (resume drafting and application assistance), social services (housing information, health insurance, benefits assistance, SNAP/HIP 2.0, food security assistance), and job opportunities. ${ }^{74}$ In April 2020, the program would have been the fifth annual

67. Indianapolis Criminal Justice Reform task Force, Criminal Justice Reform SUMMARY REPORT 1, 1-14 (Dec. 12, 2016), https://cdn.website-editor.net/2f1a0dbe13f4483ea7fce9 ab614aa453/files/uploaded/CJR\%20summary\%20report.pdf [https://perma.cc/84HJ-MJ5B].

68. See id.

69. How We Serve You: Promoting the Well-Being of Marion County Residents, Off. Pub. HEALTH \& SAFETY, https://www.indy.gov/agency/office-of-public-health-and-safety (last visited Sept. 14, 2021) [https://perma.cc/TN86-NWZK].

70. $I d$.

71. Office of Public Health and Safety Programs: Improving the Well-Being of Indianapolis Neighborhoods, OfF. Pub. HeAlth \& SAFETy, https:/www.indy.gov/activity/office-of-publichealth-safety-programs (last visited Sept. 14, 2021) [https://perma.cc/6UMZ-5CGT].

72. See id.

73. Id.

74. Nearly 400 People Served During Annual Re-Entry Fair, InD. U. RoberT H. MCKInNEY SCH. L. (Apr. 10, 2019), https://mckinneylaw.iu.edu/news/releases/2019/04/nearly-400-peopleserved-during-annual-re-entry-fair.html [https://perma.cc/38LD-9J6U]; IU Re-Entry Job \& Resource Fair, EMPLOYINDY, https:/employindy.org/event/iu-reentry-job-resource-fair/ (last visited Feb. 20, 2021) [https://perma.cc/3Y6K-FTFP]. 
event hosted by the Indiana University Robert H. McKinney School of Law, in partnership with one of the law school's student organizations, SCRAP (Second Chance Reentry Assistance Program), and 1 Like Me 501(c)(3) re-entry organization; however, it was postponed due to COVID-19. Reentry programs of this nature are highly efficacious, and much needed citywide. If sustainable, programming on this scale would serve as a model to combat "The New Civil Death" and the vicious cycle of prison poverty.

\section{Reentry Court}

The Marion County Re-entry Court program provides resources to help people who have been in jail to stay out of jail. Resources include rehabilitation and treatment services, drug screenings, and housing and employment help.

To be eligible to participate in the Re[-]entry Court program, you must meet these requirements:

- Residency in Marion County at the time of conviction and through the duration of the program

- Eligible for early release through Community Transitions program and/or parole programs

- No conduct board violations of a physical nature

- No sex offenses

The program is open to males and females, with preference given to offenders with substance abuse and addiction issues.

\section{Program Description}

People in the program are assigned a case manager. They participate in rehabilitation and treatment services, undergo regular drug screening, and receive resources to find housing and employment.

To graduate from the program, you must complete the following:

- Spend a minimum of 12 months in the program and successfully complete all three phases

- Show no positive, dilute, or missed drug screens for a minimum of 90 days

- Have steady employment or a plan to achieve professional/educational goals

- Pay in full all drug court user fees, treatment fees, and restitution

- Remain crime free

PHASE ONE

Key Concept: Recovery and Responsibility to Self

Length of phase: At least 12 weeks

Requirements:

Court attendance and office visit once weekly; random drug screens weekly; group sessions and/or life skills training classes weekly as recommended. You will be encouraged to attend twelve step recovery meetings, if necessary. 


\section{PHASE TWO}

Key Concept: Maintenance of Recovery and Responsibility to Others Length of phase: At least 12 weeks

Requirements:

Court attendance and office visit every other week; random drug screens weekly; 2 group sessions and/or life skills training weekly as recommended. You will be encouraged to attend twelve step recovery meetings weekly, if necessary.

\section{PHASE THREE}

Key Concept: Maintenance of Recovery and Responsibility to Self and Others

Length of phase: At least 90 days, to complete 12 months in program

Requirements:

Court Attendance and office visit at least every three to four weeks; at least one random drug screen per week; at least 1 group session per week if recommended. You will be encouraged to attend twelve step recovery meetings weekly, if necessary. ${ }^{75}$

In my assessment of the Re-entry Court, while it is another good example of how the City of Indianapolis government contributes to the holistic approach to reentry, combating "The New Civil Death," it could be improved to ensure that a larger percentage of people in the program successfully complete the requirements. Again, the court takes for granted that every individual has transportation to meet court and office attendance requirements. It also takes for granted that every individual can pay the fees associated with program requirements, such as drug court user fees, treatment fees, and restitution. While the requirements make logical sense, they can contribute to the poverty-prison dynamic which penalizes those who simply do not possess the financial means to pay. Based upon the current algorithms of recidivism, it seems that there is a greater likelihood that a re-entrant will recidivate under the Re-entry Court model. I would like to see the Re-entry Court relax the financial requirements to decrease the recidivism rate, while not compromising the structure and discipline necessary to foster some cognitive change.

\section{City-County Council}

In February 2014, Indianapolis City-County Council voted 26-2 in favor of the "Ban the Box" proposal, authored by Council President Vop Osili. ${ }^{76}$ Ban the

75. Re-entry Court Program: Helping People Stay out of Jail, MARION SUPERIOR CT., https:/www.indy.gov/activity/re-entry-court-program (last visited Sept. 14, 2021) [https://perma.cc/ Z5TY-FSPU].

76. Sam Klemet, Council Passes Measure on Ex-Offender Hiring, WFYI IndianAPOLIS (Feb. 25, 2014), https://www.wfyi.org/news/articles/council-passes-measure-on-ex-offender-hiring [https://perma.cc/22PM-X696]. 
Box "bars companies that contract with Indianapolis and Marion County from asking about criminal histories during initial interviews." 77 Osili stated,

"I think most of us would agree that everyone needs a fair shot at a job.

... Everyone who plays by the rules should be able to get ahead. And, everyone who makes mistakes and then owns up to those mistakes, pays for those mistakes, and then demonstrates that they have learned from those mistakes, should be given a second chance." 78

Osili also maintained that "a criminal record reduces a person's chance of getting hired by 50 percent[,] and unemployment is a key factor in returning to incarceration." 79

In 2017, the Indiana General Assembly "put an end to local 'Ban the Box' efforts" by passing Senate Bill 312, which became effective July 1, 2017, as P.L. 210-2017. "[C]odified at Indiana Code $\S 22-2-17$, [the new Ban the Box law] provides that, unless federal or state law says otherwise, a local government may not prohibit an employer from obtaining or using criminal history information during the hiring process." ${ }^{\text {" } 11}$ It is presumed that the law "passed in an effort to create uniformity throughout the State, [since it did] not include statewide limitations" on the use of an individuals' criminal background during hire. ${ }^{82}$ However, "it does create the appearance of the legislature's general disapproval of 'Ban the Box' laws." ${ }^{\text {"83 }}$ The statute states:

\section{IC 22-2-17-3 Prohibition against political subdivision prohibiting an employer from obtaining and using criminal history information initially or later in hiring process}

Sec. 3. Unless federal or state law provides otherwise, a political subdivision may not prohibit an employer from:

(1) obtaining or using criminal history information during the hiring process to the extent allowed by federal or state law, rules, or regulations; or

(2) at the time an individual makes an initial application for employment:

(A) making an inquiry regarding the individual's criminal history information; or

(B) requiring the individual to disclose the individual's

77. Id.

78. Id.

79. Id.

80. Sara R. Blevins, Indiana Bans "Ban the Box" but with New Protections for Employers and an Executive Order on "Fair Chance Hiring”, INDIANAPOLIS BAR Ass'N (Oct. 31, 2017), https://www.indybar.org/index.cfm?pg=LaborEmploymentNews\&blAction=showEntry\&blogE ntry $=6056$ [https://perma.cc/TVM2-PKLJ].

81. Id.

82. Id.

83. Id. 
criminal history information.

\section{IC 22-2-17-4 Limitation on use of criminal history information against an employer in civil action}

Sec. 4. (a) Criminal history information for an employee or a former employee may not be introduced as evidence against an employer, an employer's agents, or an employer's employees in a civil action that is based on the conduct of the employee or the former employee if:

(1) the nature of the criminal history information of the employee or former employee does not bear a direct relationship to the facts underlying the civil action;

(2) before the acts giving rise to the civil action occurred:

(A) a court order sealed the record of the criminal case;

(B) the criminal conviction has been reversed or vacated;

(C) the employee or former employee received a pardon for the criminal conviction; or

(D) the criminal conviction has been expunged under IC 3538-9; or

(3) the criminal history information concerns an arrest or a charge that did not result in a criminal conviction.

(b) This section does not supersede any federal or state law requirement to:

(1) conduct a criminal history information background investigation; or

(2) consider criminal history information in hiring for particular types of employment. ${ }^{84}$

Osili contended that "requiring job applicants to disclose criminal history puts tens of thousands of Marion County residents at an employment disadvantage and increases their risk of recidivism." ${ }^{85}$ Additionally, "[c]hecking a criminal history box can exclude candidates from even being considered for job interviews - often because of past offenses that have little or nothing to do with their ability to perform a particular job." 86 There is some good news: the new law "does not change the city's ability to exclude criminal history disclosures from its own job applications. ${ }^{" 87}$ Also, the City of Indianapolis offers incentives to companies that hire returning citizens on certain agreements. ${ }^{88}$

84. IND. CODE $\S \S 22-2-17-3$ to -4 (2017).

85. James Briggs, Briggs: Indianapolis Can't 'Ban the Box' Anymore, but a New Policy Might Have the Same Effect, InDIANAPOLIS STAR (Aug. 11, 2017), https://www.indystar.com/story/ money/2017/08/1 1/briggs-indianapolis-cant-ban-box-anymore-but-new-policy-might-have-sameeffect/555316001/ [https://perma.cc/RJ36-ALG8].

86. Id.

87. Id.

88. See id. 


\section{E. MCRC-Marion County Re-entry Coalition}

I have worked with the Marion County Re-entry Coalition over the years and applaud the efforts of each organization that belongs to the coalition. Established in 2009, the MCRC is:

a coalition of organizations and individuals who serve people re-entering the community after incarceration that works to redesign the system and create opportunities for community- and faith-based providers, as well as criminal justice agencies, to align their resources, work in collaboration and share best practices, experiences, and resources in an effort to enhance services for re-entrants in Indianapolis. The MCRC uses a results-based framework to achieve their targeted result that "all adults in Marion County involved in the justice system are successfully integrated into the community." $" 9$

In 2013, the Indianapolis City-County Council conducted a study on reentry, resulting in twenty-six recommendations which the Council deemed the MCRC responsible for advancing. ${ }^{90}$

The MCRC developed a re-entry approach that is rooted in national research and best practice. The MCRC believes that the system should include these elements if it aims to improve the likelihood of success for the returning citizen, streamline resources, and encourage agency/provider collaboration.

- Provide person-centered care

- Include a comprehensive assessment that:

- Assesses risks and needs

- Is strengths-based and builds on client resiliencies

- Is client-driven (empowering, builds client's self-efficacy)

- Offer comprehensive services and supports to meet needs identified in the assessment:

- Care coordination (wraparound approach with team-based case planning when possible)

- Community-based

- Client-driven (includes choice in services and providers)

- Culturally-responsive (gender, faith, etc.)

- Include evidence-based services that address cognitive risks/needs (e.g., cognitive behavioral therapy)

- Use peer supports and mentoring

- Provide integrated services and supports collaboration between systems and providers

- Involve families and other allies

89. What We Do, Marion COUnty Re-Entry CoAlition, https://www.marioncounty reentrycoalition.org/about (last visited Sept. 14, 2021) [https://perma.cc/FQD5-8LHY] (emphasis in original).

90. Id. 
- Support continuity of care

- Focus on the transition from incarceration (Connects re-entrants to services pre-release and provides ongoing support postrelease)

- Include ongoing monitoring and support

- Outcomes and research-driven (Evaluation)

- Include system-wide education and training (Provide capacitybuilding opportunities to agencies that serve re-entrants)

- Remove system and individual level barriers ${ }^{91}$

The MCRC works with a host of affiliate organizations, including federal, state, and local governments, non-profits, community-based corporations, and universities. In my work with the MCRC, I was the liaison between the coalition and the Office of the Mayor. I have worked with Lena Hackett, who leads the organization, and have commented, on many occasions, that the MCRC serves as the city's primary reentry organization, providing the most comprehensive and holistic plan for reentry. The participating organizations offer services that address most of the issues that create barriers to reentry that I have discussed throughout. For example, RecycleForce provides jobs specifically for reentrants ${ }^{92}$ while Horizon House addresses housing and homelessness. ${ }^{93}$ MCRC is a good example of a citywide, collective effort to combat "The New Civil Death."

\section{F. Military Veterans Model}

I have long admired the process whereby the military provides support to veterans returning to civilian life as a possible model for reentry. While all the services offered to military veterans may not be directly applicable to exoffenders, the model serves as an example of the type of holistic infrastructure necessary to reduce the recidivism rate, thereby combating "The New Civil Death." One of the departments under my portfolio of responsibility as Deputy Mayor of Neighborhood Engagement was the Office of Veteran Services, which "connect[s] veterans with the resources and opportunities available through the city's public and private partners." 94

The network of support for veterans is broad, including the U.S. Department of Veterans Affairs ("VA"). ${ }^{95}$ Services provided to veterans include housing

91. Id.

92. Workforce Training, RECYCLEFORCE, https://recycleforce.org/workforce-training/ (last visited Sept. 14, 2021) [https://perma.cc/BX63-XKMA].

93. Horizon House, https://www.horizonhouse.cc/ (last visited Sept. 15, 2021) [https:// perma.cc/GD8R-D6ZT].

94. Office of Veteran Services: Connecting Our Veterans to Local and National Resources, OFF. MAYOR, https://www.indy.gov/activity/office-of-veteran-services (last visited Sept. 15, 2021) [https://perma.cc/T9UE-2GST].

95. Veterans Services, U.S. DEP'T VETERANS AFF., https://www.va.gov/landing2_vetsrv.htm (last visited Sept. 15, 2021) [https://perma.cc/Y6EK-7KEK]. 
assistance, PTSD and drug/substance abuse counseling, addictions counseling, transportation assistance, employment assistance, healthcare, and medical services. ${ }^{96}$ Additionally:

The Indianapolis Veterans Court (IVC) helps veterans with addiction, mental illness, and injuries get treatment and improve their quality of life.

IVC provides a specialized court docket that focuses on veterans' and active-duty military members' unique needs. It also creates a therapeutic environment where structured treatment, close court supervision, and supportive interventions address impairments that can lead to criminal activity. ${ }^{97}$

In addition to providing a holistic infrastructure for veterans reentering civilian life, reentry services also exist for veterans who are incarcerated. The VA's Health Care for Re-entry Veterans program ("HCRV") "is designed to promote success and prevent homelessness among Veterans returning home after incarceration. ${ }^{98}$ HCRV services include "[o]utreach and pre-release assessments ... .[; r]eferrals and linkages to medical, mental health and social services, including employment services on release[; and s] hort-term case management assistance on release." 99

Of course, my affinity toward the veteran's reentry support infrastructure as a possible model for non-veteran prisoner reentry is meaningless without some empirical data to prove whether my theory holds any credence:

Veterans treatment courts (VTCs) are a type of problem-solving court being established all over the country in response to an increased number of justice-involved veterans with the return of military personnel from the Wars in the Middle East. Despite their rapid expansion, there is a dearth of research evaluating the impact of VTCs on recidivism. The current study conducted an impact evaluation regarding recidivism among participants of a large urban VTC program. Findings from descriptive and multivariate analysis reveal positive results for VTC participants, especially graduates, in comparison with the control group. Implications are discussed in context of three areas: (a) current criminal justice policy and practice implications for VTCs, (b) findings from research on other more established problem-solving courts (i.e., drug

96. U.S. Dep't of Veterans Affairs, Federal Benefits for Veterans, Dependents, AND SURVIVORS 7, 8, 10, 19, 48, 51 (2019).

97. Indianapolis Veterans Court Docket: Assisting Veterans with Addiction, Mental Illness, and Injuries, MARION SUPERIOR CT., https://www.indy.gov/activity/indianapolis-veterans-courtdocket (last visited Sept. 15, 2021) [https://perma.cc/K2TF-NWS3].

98. Veterans Experiencing Homelessness, U.S. DeP'T VeTERANS AfF., https://www.va.gov/ homeless/reentry.asp (last visited Feb. 15, 2021) [https://perma.cc/W6VM-WFDQ].

99. Id. 
courts), and (c) research-practitioner partnerships. ${ }^{100}$

Based upon the data, the VTC appears to effectively reduce the recidivism rate of those veterans who participated in the program at a higher rate than those who do not:

Table 2. Total Number of Re-Arrests, Type of Re-Arrest, and Recidivism Rate for VTC Treatment Groups and Control.

\begin{tabular}{|c|c|c|c|c|}
\hline & \multirow[b]{2}{*}{$\begin{array}{c}\text { Comparison } \\
\text { group } \\
(n=157)\end{array}$} & \multicolumn{3}{|c|}{ VTC general treatment group $(n=143)$} \\
\hline & & $\begin{array}{c}\text { VTC general } \\
\text { treatment } \\
\text { group }(n=143)\end{array}$ & $\begin{array}{c}\text { VTC } \\
\text { graduates } \\
(n=127)\end{array}$ & $\begin{array}{c}\text { VTC } \\
\text { terminated }^{x} \\
(n=16)\end{array}$ \\
\hline Total number of re-arrests & 44 & 34 & 18 & 16 \\
\hline \multicolumn{5}{|l|}{ Re-arrest offenses ${ }^{c}$} \\
\hline DWI & $13(30 \%)$ & $15(43 \%)$ & $7(39 \%)$ & $8(50 \%)$ \\
\hline Person (assault) & 5 (11\%) & $5(15 \%)$ & $4(22 \%)$ & $1(6.3 \%)$ \\
\hline Public order & $10(23 \%)$ & $6(18 \%)$ & $5(28 \%)$ & $1(6.3 \%)$ \\
\hline Property & II (25\%) & 0 & 0 & 0 \\
\hline Drug & $5(11 \%)$ & $8(24 \%)$ & $2(11 \%)$ & $6(37.5 \%)$ \\
\hline Mean number of re-arrests & $0.30(0.79)$ & $0.24(0.74)$ & $0.14(0.55)^{d}$ & $1.06(1.39)$ \\
\hline \multicolumn{5}{|l|}{ Individuals re-arrested } \\
\hline I re-arrest & $13(8.3 \%)$ & $13(9.1 \%)$ & $7(5.5 \%)$ & $6(37.5 \%)$ \\
\hline 2 re-arrests & $8(5.1 \%)$ & $2(1.4 \%)$ & $2(1.6 \%)$ & 0 \\
\hline 3 re-arrests & $2(1.3 \%)$ & $2(1.4 \%)$ & $\mathrm{I}(0.8 \%)$ & $1(6.3 \%)$ \\
\hline 4 re-arrests & $3(1.9 \%)$ & $3(2.1 \%)$ & $1(0.8 \%)$ & $2(12.5 \%)$ \\
\hline Total recidivism rate ${ }^{e}$ & $26(16.6 \%)$ & $20(14 \%)$ & $11(8.7 \%)$ & $9(56.3 \%)$ \\
\hline
\end{tabular}

Note. $\mathrm{VTC}=$ veterans treatment court; DWI $=$ driving while intoxicated.

'The general treatment, graduate, and terminated groups are not mutually exclusive as the general treatment group is comprised of both graduates and terminated participants who participated in the program for at least 6 months.

'This is not a measure of the number of people re-arrested but reflects the total number of re-arrests. The number of individuals re-arrested is also displayed at the bottom of the table.

cPercentages are out of the total number of re-arrests (row above). DWI offenses include DWI first $D W I>0.15, D W I$ second, and obstruction of highway; person offenses include assault with bodily injury and assault with a deadly weapon; public order offenses include unlawful carrying of a weapon, violation of a protection order, public intoxication, and fallure to ID or providing false information; property offenses include theft and criminal mischief; Drug offenses include possession of marijuana, possession of a controlled substance.

The difference in the mean number of re-arrests between VTC graduates and the comparison group is statistically significantly at the $p \leq .05$ level.

'This is the actual number of individuals re-arrested versus the total number of re-arrests.

[A]cross all time-at-risk periods, VTC graduates have the lowest mean number of re-arrests. At 12 months time at risk, VTC graduates had 0.14 average rearrests, VTC general participants had 0.25 average re-arrests, and the comparison group had 0.40 average re-arrests. Although mean re-arrests between the VTC general participant and control group were not statistically significant, VTC graduates had almost 3 times fewer average re-arrests than the comparison group, which was statistically significant at $p \leq .05$. At 24 months, VTC graduates still

100. Richard D. Hartley \& Julie Marie Baldwin, Waging War of Recidivism Among JusticeInvolved Veterans: An Impact Evaluation of a Large Urban Veterans Treatment Court, 30 CRIM. Just. PoL'y ReV. 52, 52 (2019). 
had the fewest average re-arrests. ${ }^{101}$

\section{CONCLUSION}

As it turns out, "The New Civil Death" is not so new, based upon the data. In fact, a slow civil death has occurred for decades in the form of mass incarceration, lack of resources resulting in ineffective reentry programs, and policy level decisions that perpetuate a vicious cycle of INCARCERATION $\rightarrow$ POVERTY $\rightarrow$ RECIDIVISM, with poverty as the nexus. I asked the early question: Is it working? The short answer is no-and it will not-unless there is a holistic approach to reentry that begins during the pre-release phase of an inmate's journey that provides support and resources upon reentry. The cycle of incarceration, poverty, and recidivism can be broken only if a holistic approach is implemented. I mentioned a theoretical Recidivism Reduction Program as general nomenclature for a proposed infrastructure designed to effectively reduce the recidivism rate.

The Ohio Plan is a good example of a program that yields favorable results. Ohio has a slight edge over Indiana in reduced recidivism rates, but according to the Indiana Department of Correction, the recidivism rate in Indiana is $33.78 \%$ for both people facing a new conviction or violating parole. ${ }^{102}$ This is the lowest rate in Indiana in six years. ${ }^{103}$ I provided a very detailed explanation of what we are doing here in Indianapolis. "Ban the Box" is an example of a milestone piece of local legislation that would preclude employers from denying positions to individuals with a criminal record, based upon a job application. However, the Indiana state legislature diminished its potency to some degree, making it challenging to fully adopt a true ban of the box.

The degree to which mass incarceration is a tool of systematic racism must not be understated. The Thirteenth Amendment states, "Neither slavery nor involuntary servitude, except as a punishment for crime whereof the party shall have been duly convicted, shall exist within the United States, or any place subject to their jurisdiction." ${ }^{04}$ A Netflix documentary directed by Ava DuVernay in 2016 suggests that the Thirteenth Amendment, ratified in 1865, permits and perpetuates slavery via a loophole found in the language of involuntary servitude. ${ }^{105}$ Based upon the disparate incarceration numbers and mass incarceration of black and brown people, such a loophole rings true.

Michelle Alexander further suggests that mass incarceration is the "New Jim Crow." 106 Both DuVernay and Alexander discuss the racial implications of mass incarceration over the last thirty years. ${ }^{107}$ In thirty years, the U.S. penal population

101. Id. at 60 tbl.2, 67 .

102. Crown, supra note 46.

103. Id.

104. U.S. Const. amend. XIII.

105. 13TH (Netflix 2016).

106. See AleXANDER, supra note 11.

107. See id.; 13TH, supra note 105. 
increased from 300,000 to over 2,000,000, with drug convictions accounting for the majority of the increase. ${ }^{108}$ The U.S. rate of incarceration is 698 per 100,000 people, ${ }^{109}$ compared to 161 in the U.S. in $1972,{ }^{110}$ and 70 in Germany today. ${ }^{111}$ Blacks make up $13.4 \%$ of the U.S. population, ${ }^{112}$ but $38.6 \%$ of the U.S. incarcerated population. ${ }^{113} \mathrm{~A}$ third of black men will have served time in prison, based on 2001 statistics. ${ }^{114}$ Since 1980, the growth in number of arrests for black Americans has been concentrated in drug crimes while arrests for property and violent crimes have decreased. ${ }^{115}$ Drug offenses make up $46 \%$ of inmates in federal prisons ${ }^{116}$ and almost $15 \%$ in state prisons. ${ }^{117}$ Unless changes are made at the policy level that address an out-ofcontrol prison population issue, the United States will continue to grapple with consequences of its own putative design.

Nevertheless, there are many positive efforts and initiatives within our own community to combat "The New Civil Death." For example, in 2016, Mayor Hogsett initiated a full-scale criminal justice reform plan that included the construction of a criminal justice campus center. ${ }^{118}$ The campus includes an Assessment and Intervention Center, which opened December 1, 2020, and serves as an "off ramp," or an alternative to incarceration for individuals suffering addictions and mental illness. ${ }^{119}$ Additionally, the Office of Public Health and Safety, Marion County Re-entry Court, Marion County Re-entry Coalition, and

108. $13 \mathrm{TH}$, supra note 105.

109. Peter Wagner \& Wanda Bertram, "What Percent of the U.S. Is Incarcerated?" (And Other Ways to Measure Mass Incarceration), Prison POL'Y InITIATIVE (Jan. 16, 2020), https://www.prisonpolicy.org/blog/2020/01/16/percent-incarcerated/ [https://perma.cc/5USNDN5V].

110. The Growth of InCARCERAtion In the United States 33 (Jeremy Travis et. al. eds., 2014).

111. Germany, WORLD PRISON BRIEF, https://www.prisonstudies.org/country/germany (last visited Oct. 28, 2021) [https://perma.cc/C7AM-XJHV].

112. QuickFacts: United States, U.S. CEnsus BurEaU, https://www.census.gov/ quickfacts/fact/table/US/PST045219 (last visited Sept. 14, 2021) [https://perma.cc/57K3-KXPR].

113. Inmate Race, FED. BUREAU PRISONS, https://www.bop.gov/about/statistics/statistics inmate_race.jsp (last visited Feb. 22, 2021) [https://perma.cc/X8YW-SBAR].

114. Thomas P. Bonczar, Prevalence of Imprisonment in the U.S. Population, 1974-2001, Bureau Just. StAT. at 1 (Aug. 2003), https://www.bjs.gov/content/pub/pdf/piusp01.pdf [https:// perma.cc/D36Y-B5BD].

115. See Howard N. Snyder, Arrests in the United States, 1980-2009, Bureau Just. Stat. (Sept. 2011), https://www.bjs.gov/content/pub/pdf/aus8009.pdf [https://perma.cc/ZW9N-GMTB].

116. Offenses, FeD. BurEAU Prisons, https://www.bop.gov/about/statistics/statistics_inmate_ offenses.jsp (last visited Sept. 14, 2021), [https://perma.cc/WGF3-77Q4].

117. See Wendy Sawyer \& Peter Wagner, Mass Incarceration: The Whole Pie 2020, Prison PoL'y Initiative (Mar. 24, 2020), https://www.prisonpolicy.org/reports/pie2020.html [https:// perma.cc/BB83-U5KU].

118. Consolidated City of Indianapolis \& Marion Cty. Exec. Order No. 4, 2016 (May 11, 2016).

119. Pak-Harvey, supra note 12. 
Office of Veteran Services all offer reentry programs that connect returning citizens to resources that will buttress successful reentry into the Indianapolis community after serving jail or prison terms. ${ }^{120}$ However, Marion County maintains roughly a $55 \%$ recidivism rate, ${ }^{121}$ which reveals room for improvement when compared to the state average of $33.78 \%$. $^{122}$

Overall, when programs exist at the pre-release stage - following a returning citizen through reentry, and intentionally providing resources to succeed - such programs combat "The New Civil Death," and reduce recidivism rates with proven levels of success.

120. See Office of Public Health and Safety Programs, supra note 71; Re-entry Court Program, supra note 75; What We Do, MARION COUNTY Re-Entry COALITION, supra note 89; see also supra Section III.F.

121. RBA: Reducing Recidivism in Marion County, Community Solutions, https://www. communitysolutionsinc.net/mcrc (last visited Oct. 28, 2021) [https://perma.cc/Q4C8-W8SW].

122. Crown, supra note 46. 